\title{
Nymph and corpuscle. Transformations of the Aqua Virgo
}

\author{
FRANK FEHRENBACH
}

In a letter dated July 26,1543 , published in 1550 , Claudio Tolomei laments the condition of an antique Roman aqueduct:

She [the Aqua Virgo] is the only one of all the aqueducts which is still alive [e rimasa anchor viva], and she comes to Rome, and fulfills many needs, and she ennobles those gardens that are close to her, although she feels the wounds of age and time; and a large part of her is already lost which could [however] easily be recuperated by the industry and diligence of men. ${ }^{1}$

The humanist Tolomei, a protagonist of the passionate movement to build urban gardens and grottoes after the destructions of the Sacco in 1527, evokes the characteristic combination of nostalgia and technological appeal, of »the lure of antiquity and the cult of the machine « which has been reconstructed so impressively by Horst Bredekamp (1995). The object of desire is an antique hi-tech product that had lost most of its liveliness (viz. function) in Tolomei's day. But not completely, and thus the unrestricted lamentation of ruins turns into a demand. It is the surprising robustness of the rill which keeps the memories of the conduit's former grandeur alive. And it is the historical continuum, ensured by the aqueduct's continuous flow, that marks the core of the cultural transformation to which I dedicate the following pages.

Aqua Virgo survived the decline of the Western Roman Empire and remained to a large extent undestroyed, in contrast to the other ten classical Roman aque-

1 »[...] la qual sola di tutte l'altre acque è rimasa anchor viva, e viene a Roma, e soviene a molti bisogni, e fa nobili que'giardini che le son d'appresso; benche anchora ella sente i morsi de la vecchiezza, e del tempo; e buona parte se n'è già perduta, la qual potrebbe con l'industria, e diligenza de gli huomini agevolmente riguardarsi.« Cited after Davis (1976/1977), 141, n. 37. Cf. MacDougall (1978). The groundbreaking monograph on the Fontana di Trevi and its conduit remains Pinto 1986. - The argument of this rapid sketch is extensively developed in my forthcoming Compendia Mundi. Gianlorenzo Berninis Fontana dei Quattro Fiumi und Nicola Salvis Fontana di Trevi. Kunst, Naturphilosophie, Topographie, Munich etc. 2007 (Deutscher Kunstverlag). I wish to thank Beatrice Kitzinger for her assistance. 
ducts. $^{2}$ As the shortest of these aqueducts, Aqua Virgo runs mainly in underground channels (fig. 1), a fact that saved it from the ssurgical war actions of the Ostrogoths and, later on, the Langobards, during their sieges of the urbs.

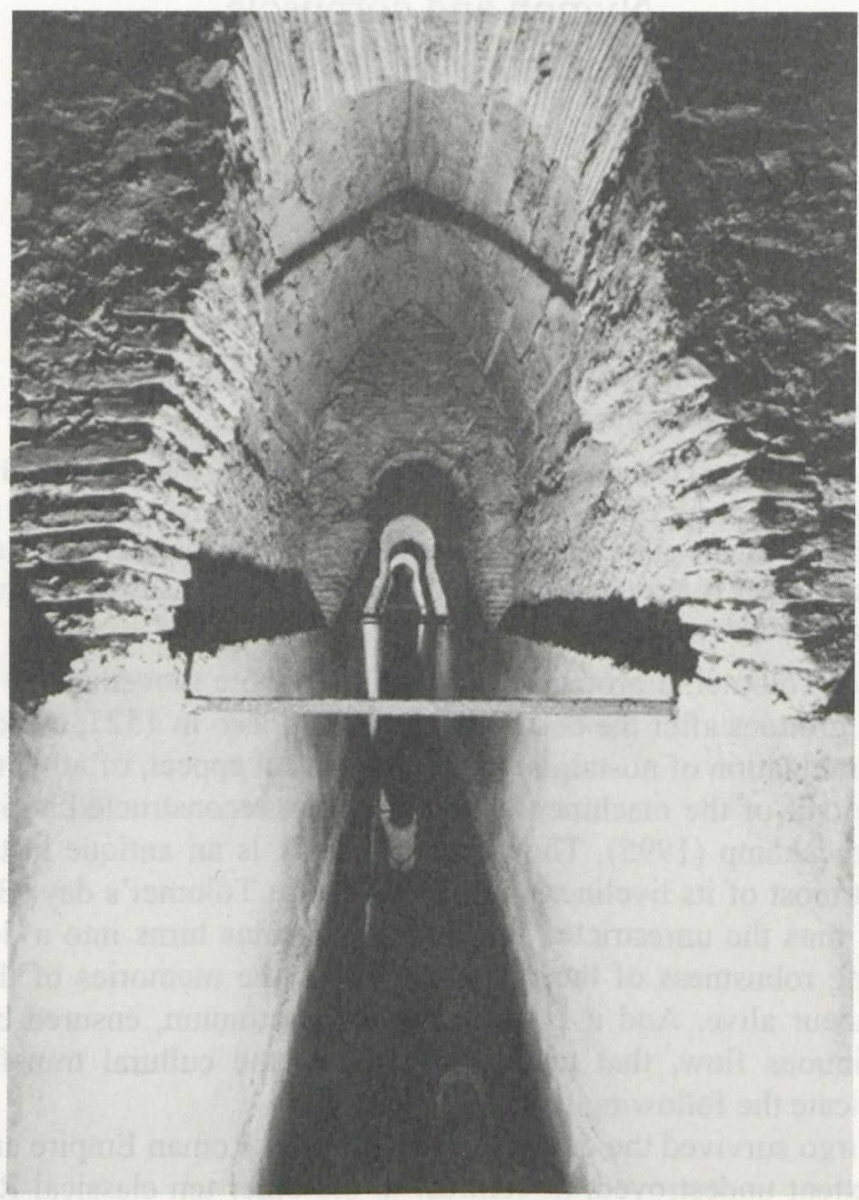

Fig. 1: Underground channel of Aqua Virgo.

Nevertheless, the conduit fell into ruin, because aqueducts require an effective public administration and a credible police power. As everybody knows, even today the state of public water supply is an exact indicator for the corruption of public government. Built in 19 BCE by Agrippa, the son-in-law of Augustus, the >Virgin conduit< originally fed the first monumental public baths on the Campus

2 For the history of the Roman aqueducts and water supply see Taylor (2000). Especially for the Aqua Virgo cf. Pinto (1986), 5 ff. 
Martius, the flat area between the hills and the Tiber. It was here that the shrinking population began to build medieval Rome, half a millenium later. The urban organism reflects in its movement one of the most important metabolic fundamentals of society - the accessibility of water. After the decline of the artificial streams - the aqueducts -, the natural course of the Tiber became again Rome's main artery, as in the city's legendary first four hundred years, providing abundant, but low quality, water, while continuously threatening the population with floods and epidemics. ${ }^{3}$

As though from the open wound of historic humiliation, though, water still trickled from the lymph of the Aqua Virgo. Meanwhile, the area to the Northeast of Rome where the aqueduct's sources were collected became increasingly marshy, and its antique end point in the Pantheon area fell into ruin. But the truncated conduit, now ending close to the Trevi fountain, still offered its (decidedly distasteful) waters.

However, antique literature recalled the original, singular purity of the conduit. ${ }^{4}$ Besides the vaunting descriptions of its therapeutic effects by classical Roman authors, the legends of the aqueduct's foundation also make this point explicit. Right at the beginning of his standard reference book, De aquis urbis Romae, Sextus Julius Frontinus, chief administrator of the roman water supply under Traianus, describes the finding of the source at Salone by thirsty soldiers of Agrippa, aided by a local girl (virgo) who indicated the site to the cohort (fig. 2).

Virgo appellata est, quod quaerentibus aquam militibus puella virguncula venas quasdam mostravit, quas secuti qui foderant, ingentem aquae modum invenerunt. [...] signino circumiecto continendarum scaturiginum causa. ${ }^{5}$

Obviously, the connection of military virtus and a maiden's castimonia contributed to the popularity of the Roman legend. Following Frontinus and Cassiodorus, Agrippa inaugurated his work, significantly, on June $9^{\text {th }}$, the feast day of the Vestals, women who, as virginal priestesses, took care not only of the fire in the hearth, but also of the holiness and purity of water. ${ }^{6}$

3 Cf. Krautheimer (1981), $86 \mathrm{ff}$. and passim; furthermore D'Onofrio (1986), $33 \mathrm{ff}$.

4 Cf. the survey by Lombardi (2003).

5 De aquis urbis Romae I, 10. - Cf. Pace (1986); Bruun/Saastamoinen (2003). On Frontinus' work in the perspective of the history of technology, Landels (1979), 257-262.

6 Simon (1990), $229 \mathrm{f}$. 


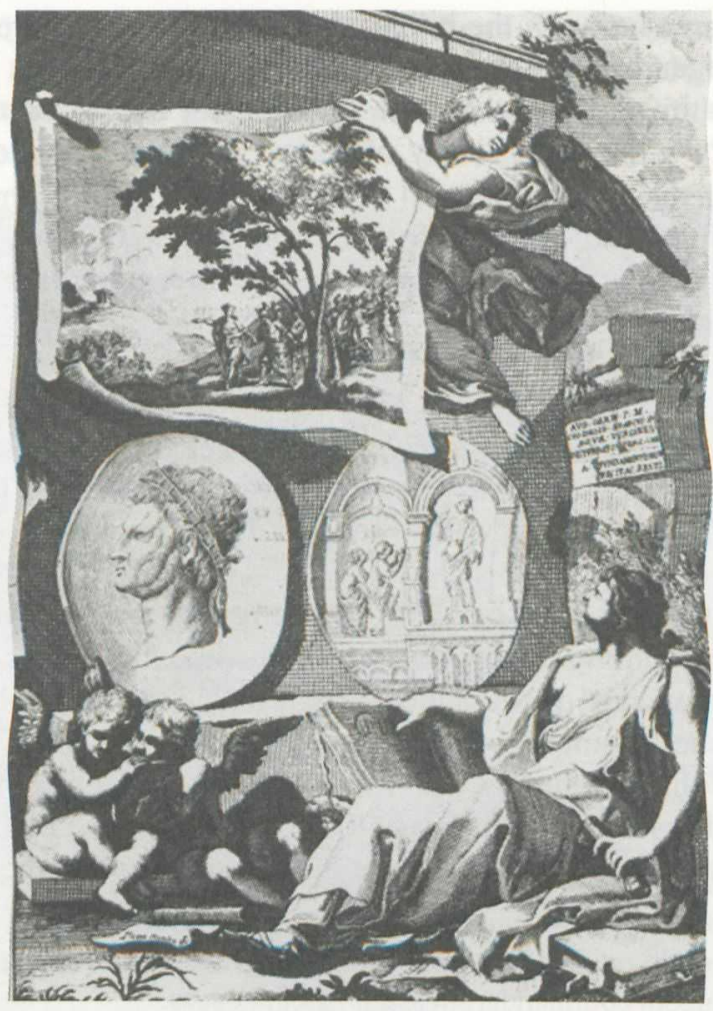

Fig. 2: Legend of the Aqua Virgo (after Graeve, Thesaurus 1732).

This hydraulic sacrality - sit venia verbo - of the Aqua Virgo continued in the Middle Ages, a continuity mirrored in an event that took place just a few steps from the fountain - the miracle of S. Maria in Via. ${ }^{7}$ In the night between $26^{\text {th }}$ and $27^{\text {th }}$ September 1256 , an adjacent well suddenly overflowed and flooded a stable. The terrified eyewitnesses soon noticed that an image of the Madonna swam on the undulating waters (fig. 3). Painted on stone, the image could only be grabbed, however, after the owner of the palace, Cardinal Pietro Capocci, approached and prayed in front of the well. According to local legend, S. Maria in Via, a relatively unimportant church before, was lavishly rebuilt after the miracle. More probably, only a new chapel was commissioned that incorporated the holy well. Pope Alexander IV. Conti inserted the (ducentesque) painting into the corpus of Roman icons and allowed its public veneration. Cardinal Capocci donated the

7 Until now, literature on S. Maria in Via and the miracle of the well is virtually inexistent. For some outlines see the few pages of Cecchelli (n. d.). 
altar relics - among them, most prominently, a stone from Jacob's well, where Christ proselytized the Samaritan woman.

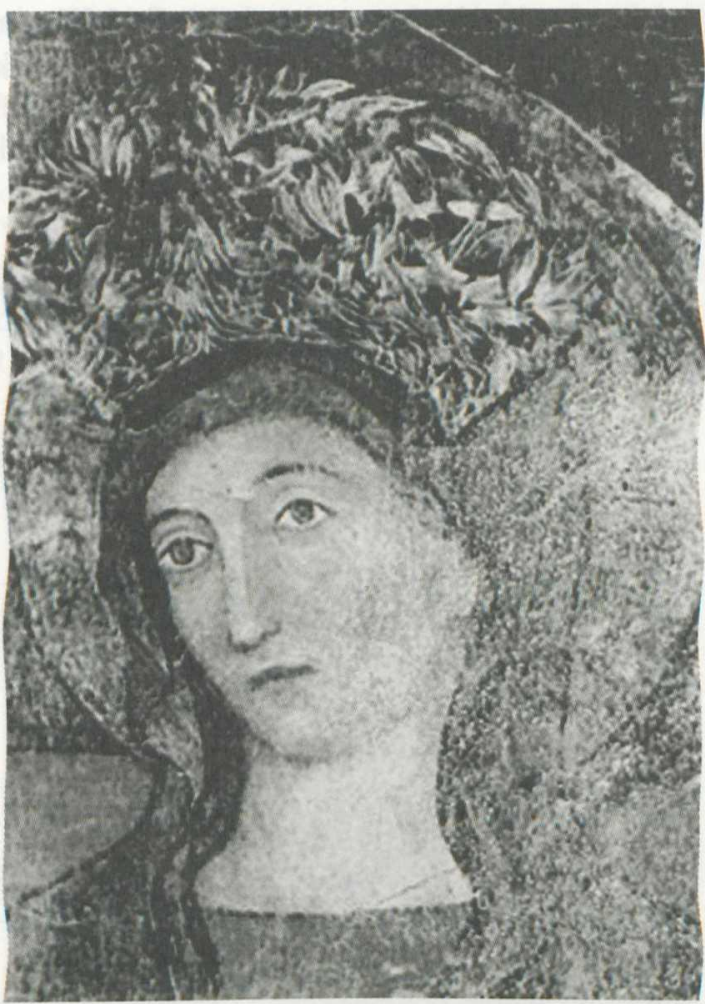

Fig. 3: Madonna del Pozzo (Santa Maria in Via, Rome).

Soon, the chapel of the new icon became very popular, due to the fact that the faithful were (and still are) invited to drink from the sacred waters of the well (fig. 4). This should be contrasted to the remarkably bad sanitary conditions of the urbs in the $13^{\text {th }}$ century, already emphasized by a shuddering Ferdinand Gregorovius. $^{8}$ One of the main reasons for this was, of course, the chronic problem of water supply. Indeed, the Tiber still provided drinking water for the city, but general hygiene was severely damaged by the neglect of wells and cisterns. Viewed in this context, it is highly significant that the miracle of the well occurred very close to Aqua Virgo, but in an area sbefores the waters of the conduit arrived at Piazza di Trevi, thus claiming almost literal priority over the mouthpiece of the aqueduct. The water of the holy well is actually probably provided by

8 Cf. Gregorovius (1892), Bd. 5, 628. On medieval Roman water supply Coates-Stephens (2003). 
the pipes of the Aqua Virgo, as recent archival findings by Eva Helfenstein implicate. ${ }^{9}$ Therefore, the nocturnal event at S. Maria in Via seems to respond to an urgent administrative and technological need - the renovation of the antique conduit - by means of a miracle, demonstrating how God Himself forces potable water to rise abundantly, thus substituting the virgo of the aqueduct by the Virgo, Mother of God. The event sheds some bright light on the implicit provocation by the Aqua Virgo as a venerated reminder of the inimitable miracles of antique ars mechanica.

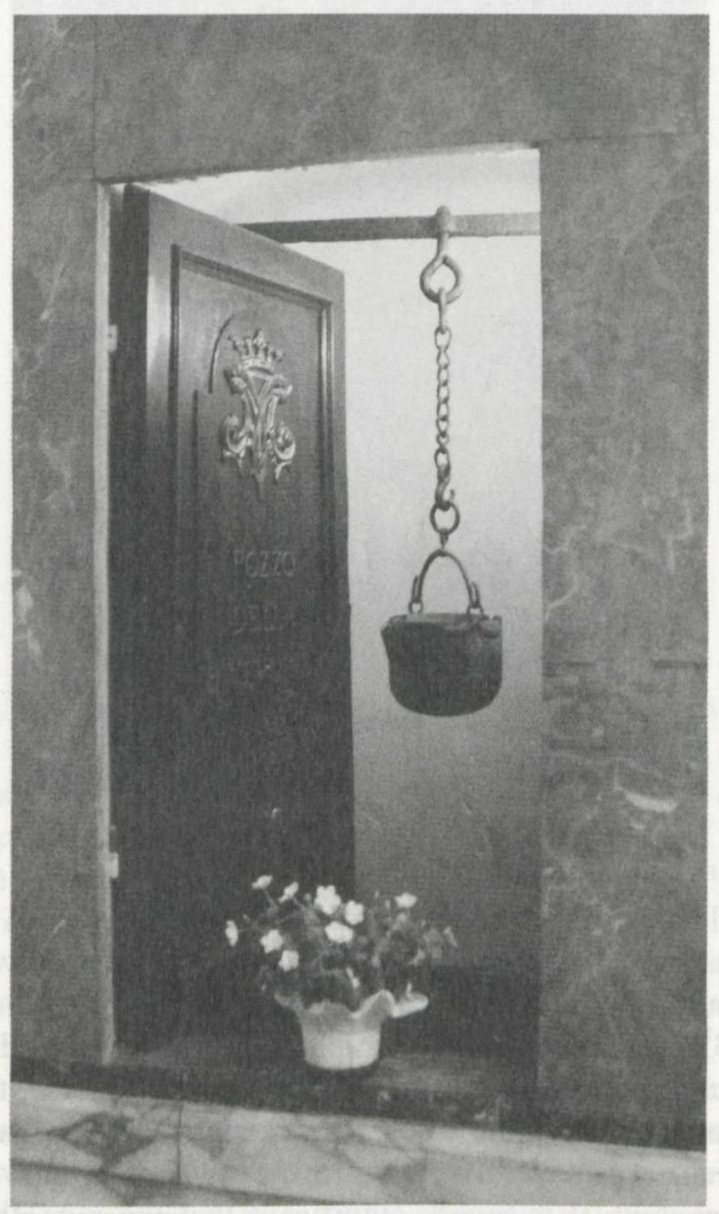

Fig. 4: Chapel of the Madonna del Pozzo (Santa Maria in Via, Rome).

9 Among other relevant documents, the Archivio del Convento di S. Maria in Via conserves a Concessio aquae Virginis pro ecclesia S. Maria in Via from 1639 (inv. IV 14 a). 
Strangely enough, none of the periodic efforts to renovate the aqueduct included the time-honored fountain in the Rione Trevi, de jure administered by the Roman comune at least since the High Middle Ages. Nicolaus V. provided the fountain with a rather modest, old-fashioned, crennelated façade (fig. 5), but his successors, Renaissance popes like Julius II., Leo X., Paul III., or Sixtus V., who radically transformed Rome, did not dare to lay their hands on the provocatively simple building, not even after August 16, 1570, one day after Assunta (!), when the antique abundance of water became finally available again, thanks to restaurations under Pius V. ${ }^{10}$ Only towards the end of Urban VIII. Barberini's pontificate, was the time finally ripe to demolish the mouthpiece of the Aqua Virgo. Gianlorenzo Bernini was commissioned to move the fountain by ninety degrees in order to make it visible from the Quirinal palace, the papal summer residence (fig. 6).

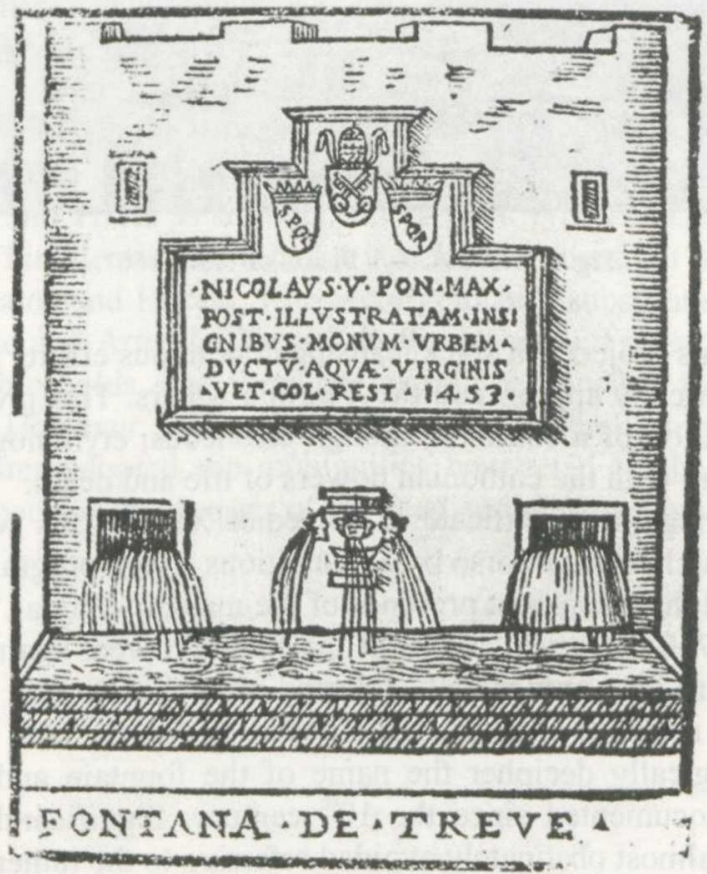

Fig. 5: The Trevi Fountain of Nicholas V (after Franzini, Descrittione, 1643).

10 Cf. D’Onofrio (1986), 62. 


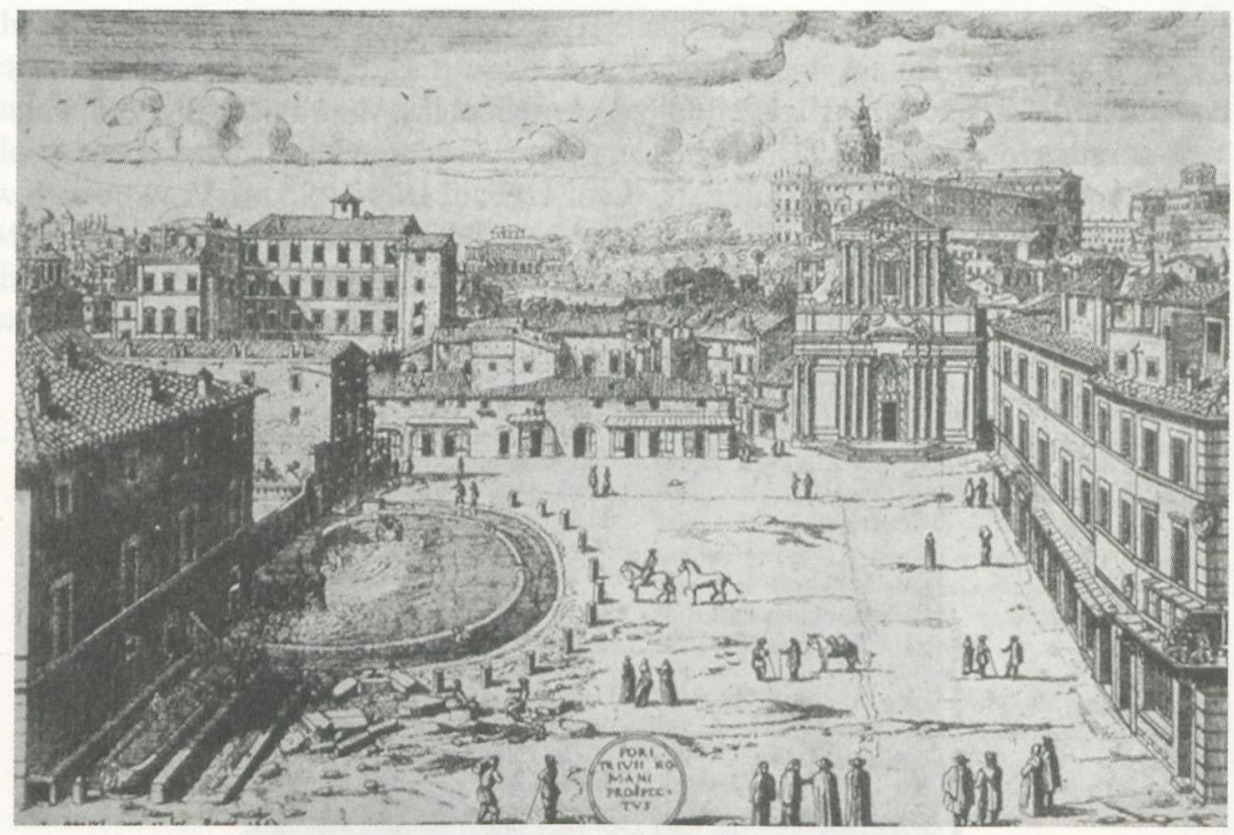

Fig. 6: Lieven Cruyl, Piazza di Trevi, 1667.

However, even this project got stuck, causing continuous efforts for the next ninety years to dynastically appropriate the Virgin's waters. This process is reflected in the transformation of a common, though erroneous, etymology that identified the ancient conduit with the chthonian powers of life and death.

In 1728 , during the pontificate of Benedict XIII., plans were approved to adorn Bernini's architectural torso by an ambitious figure program, with a presiding Madonna and the prominent presence of the maiden >Trivia $<.{ }^{11}$ After the death of the pope in 1730, however, works at the fountain were again interrupted and the entire program was immediately rejected after the election of Clement XII. Corsini. >Trivia refers to an antiquarian debate of the $16^{\text {th }}$ and $17^{\text {th }}$ century that tried to etymologically decipher the name of the fountain and of the Rione Trevi, a name documented since the $10^{\text {th }}$ century. Significantly, until the $18^{\text {th }}$ century, authors almost obstinately avoided referring to the rather evident fact that Piazza di Trevi conserves an important antique three-way crossing. ${ }^{12}$ Instead, authors like Fra Mariano da Firenze, Pomponio Leto, Bartolommeo Marliano, Lucio Fauno, Lucio Mauro, Pirro Ligorio, Bernardo Gamucci, Fioravante Marti-

11 A sarcastic summary of the program is provided by the diarist Francesco Valesio; cf. Valesio, Diario (ed. Scano - Graglia, vol. 4, 966); Pinto (1986), App. I, 4.

12 Cf. Ceen (1986), 67-73. 
nelli, and Famiano Nardini referred constantly to the nymph Juturna, the sister of Turnus, King of the Rutules. Her name, these authors state, became corrupted as >Lotreglio< which finally mutated into >Trevis. Thus all the authors agree upon the connection between Aqua Virgo and a female figure who was well known - according to Ovid, among many others - as the main nymph of Rome. At her feast day, January $11^{\text {th }}$, the Iuturnalia were celebrated, the culmination of the Roman cult of nymphs. - But what about the identification of Juturna with >Trivias?

The arguments of the antiquarian literature are disturbingly opaque. Juturna is characterized as a numen mixtum ${ }^{13}$ and merges with her leader Diana, chief of the nymphs. It was Andrea Bacci in his treatise on thermal baths (De thermis, Venice 1571 , with many editions) who related for the first time the name of Rione and fountain - Trevi - clearly to Diana Trivia. The most relevant passages of Bacci's compendium are quoted by Jean Chiflet in 1662 and authoritatively repeated in Graeve's monumental Thesaurus, published in the year of Clement's commission, 1732. ${ }^{14}$ Chiflet backs this argument by an extensive apparatus, referring to the main loci on the Aqua Virgo. The title of the publication already underscores the connection between the fountain and the cult of the nymphs (Fons Romae celeberrimus, et prisca religione sacer).

The identification of Diana and Trivia is confirmed by Ovid's authority. ${ }^{15} \mathrm{He}$ refers to Apollo and Trivia as siblings and invokes Trivia as Diana with the three virgin's faces. This identification had a Greek antecedent. At its origins we find the siblings Hecatos and Hecate, who were gradually substituted, in the classical period, by Apollo and Artemis-Diana. ${ }^{16}$ Both brother and sister were guardians at doorways and thresholds, and therefore mainly responsible for defense against hostile demons. However, while Hecatos became gradually transformed into the sun god, his sister adopted the ambiguities connected to the enchantments at thresholds. She became the >master of the dead and ghosts ( fig. 7). ${ }^{17}$

13 Cf. Panofsky (1960), 36 ff.

14 Graeve (1732), vol. 4, col. 1785-1795.

15 Ovid, fast. I, 389. - On Trivia Diana Ephesia cf. Pirro Ligorio, Libro dell'antichità, voce »Pyramidi« (commentary on Martial).

16 See Kraus (1960).

17 Ibid., 20. 


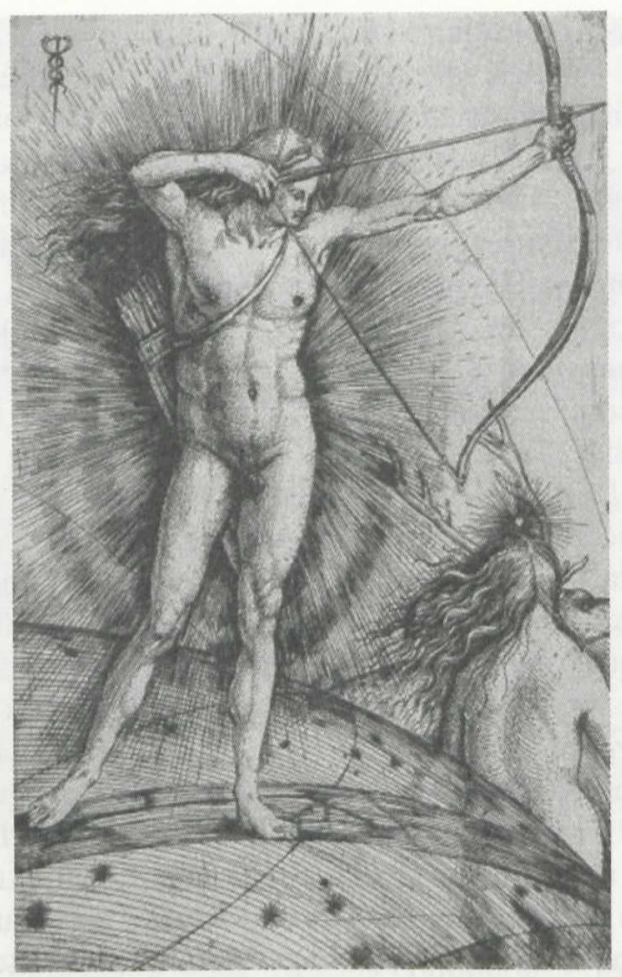

Fig. 7: Jacopo de'Barbari, Apollo and Diana, engraving, c. 1503-1504.

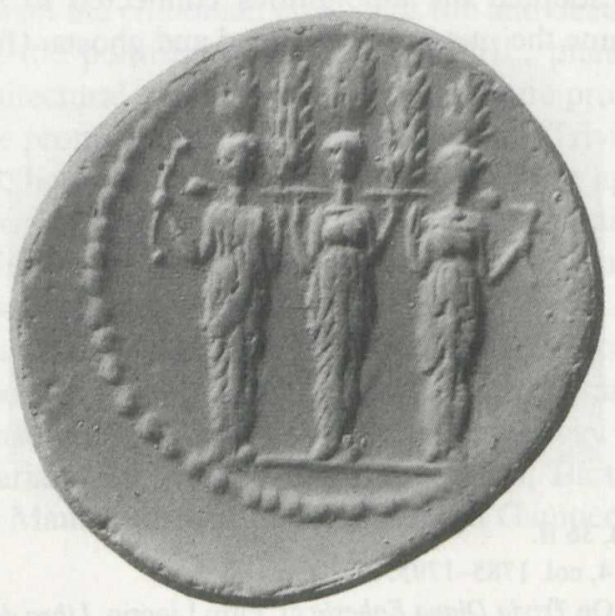

Fig. 8: Diana-Trivia of Aricia, Roman denar, 43 BC. 


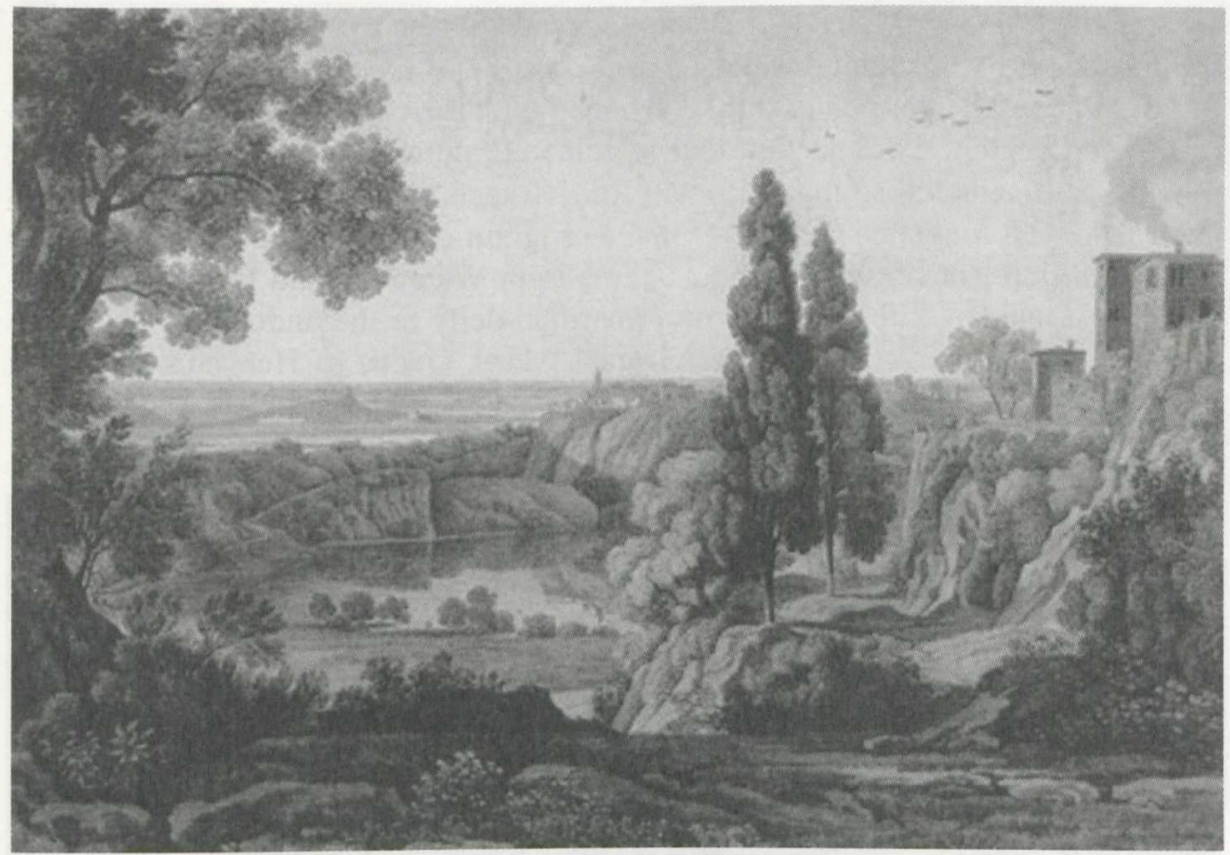

Fig. 9: Carl Ludwig Kaaz, Lake of Nemi, Karlsruhe, Staatliche Kunsthalle.

In Rome, Diana-Trivia's main cult site was located outside the city, in the grove of Diana Nemorensis, at the lake of Nemi, Triviae [...] lacus (fig. 8; 9). ${ }^{18}$ Beginning in the time of Sulla, every fourth year the urbs celebrated a great feast both for Diana-Trivia and Roma - a significant double dedication that was probably intended to neutralize the chthonic character of the protective deity Trivia. Trivia was mainly responsible for two-way (bivii) and three-way forks (trivii); here, she was believed to protect against aberrances caused by demoniac inspiration. Attentively, she watches out at three sides. ${ }^{19}$ At night, passengers and travelers have to call her loudly at the trivii of the cities: »nocturnisque Hecate triviis ululata per urbes ${ }^{20}$

At this point, the argument comes full circle, demonstrating that humanist etymologies tried to adjust the name of the aqueduct to its topographic situation. The core of this actualization through translation is marked by the following thesis: In the center of the Rione Trevi lies an antique trivius which is presided and guarded, like all the classical three-way forks, by Trivia alias Diana. Three-way situations required guardian deities - most prominently Trivia. Trivia protects and

18 Ovid, fast. VII, 516. - On Diana see Simon (1990), 51-58.

19 Ovid, fast. I, 141-142.

20 Ibid., IV, 609. 
at the same time, in the shape of Diana, the leader of the nymphs, takes responsiblity for the purity of running waters. ${ }^{21}$

Significantly, a hi-tech past is here linked with the cult of the chthonic powers of life and death - a connection that is mirrored, more playfully, in the sleeping nymph that decorated so many Roman Renaissance and Baroque garden grottoes and rustic wall fountains (fig. 10). ${ }^{22}$ If the program of 1728 had been realized, the most dignified Roman water conduit, the Virgin Waters, would have been dominated by a maiden with the name of a guardian deity of the underworld, but concurrently presided over by another virgin - Mary, Queen of Heaven high above the waters of the fountain.

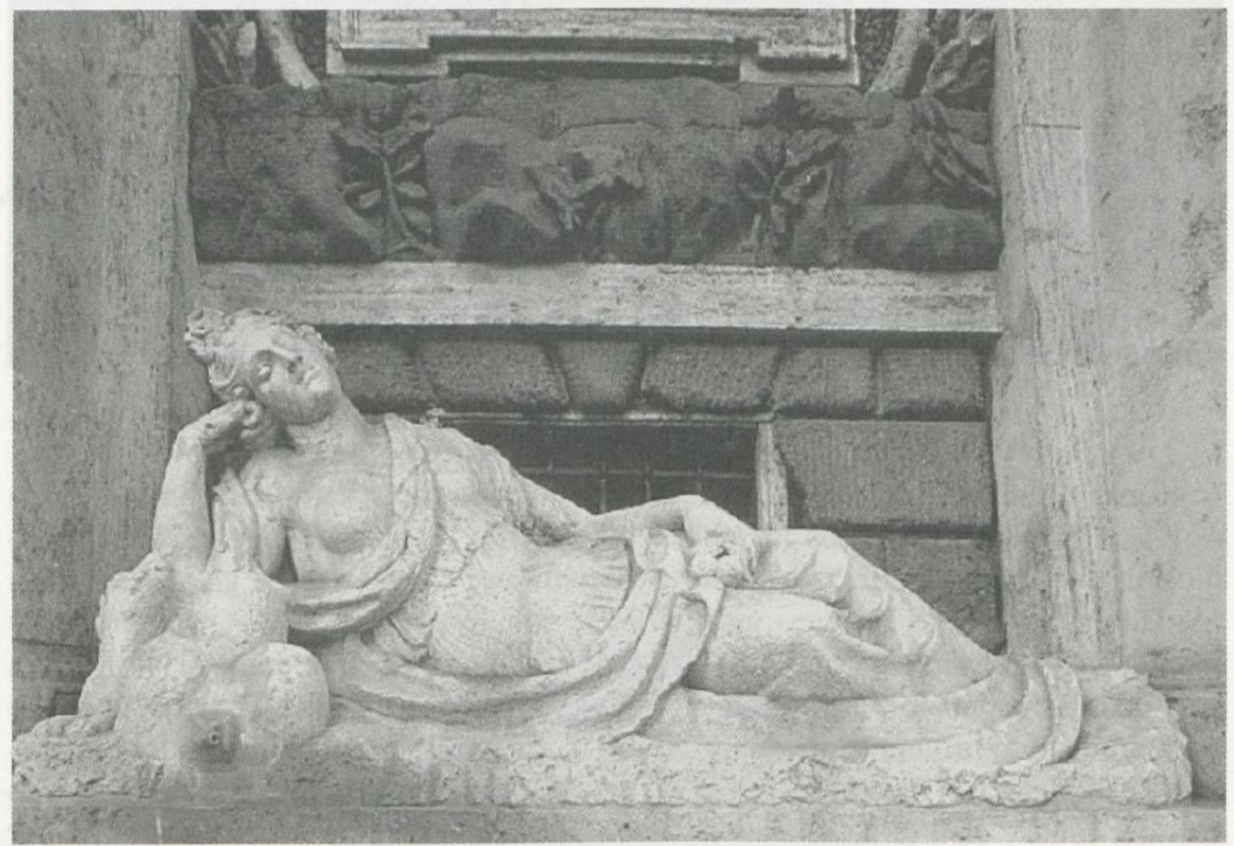

Fig. 10: Anonymous, Sleeping Diana, Quattro Fontane, Rome, c. 1590.

Within a few months this program - quite astonishing in terms of gender history was radically transformed, now featuring a figure who represents the material existence of the entire world. Through this radical shift, the Virgin Waters became corpuscles, and the nymph a man.

21 On this aspect of the nymphs $\mathrm{cf}$. ibid., IV, $757 \mathrm{ff}$.

22 Cf. MacDougall (1975). 


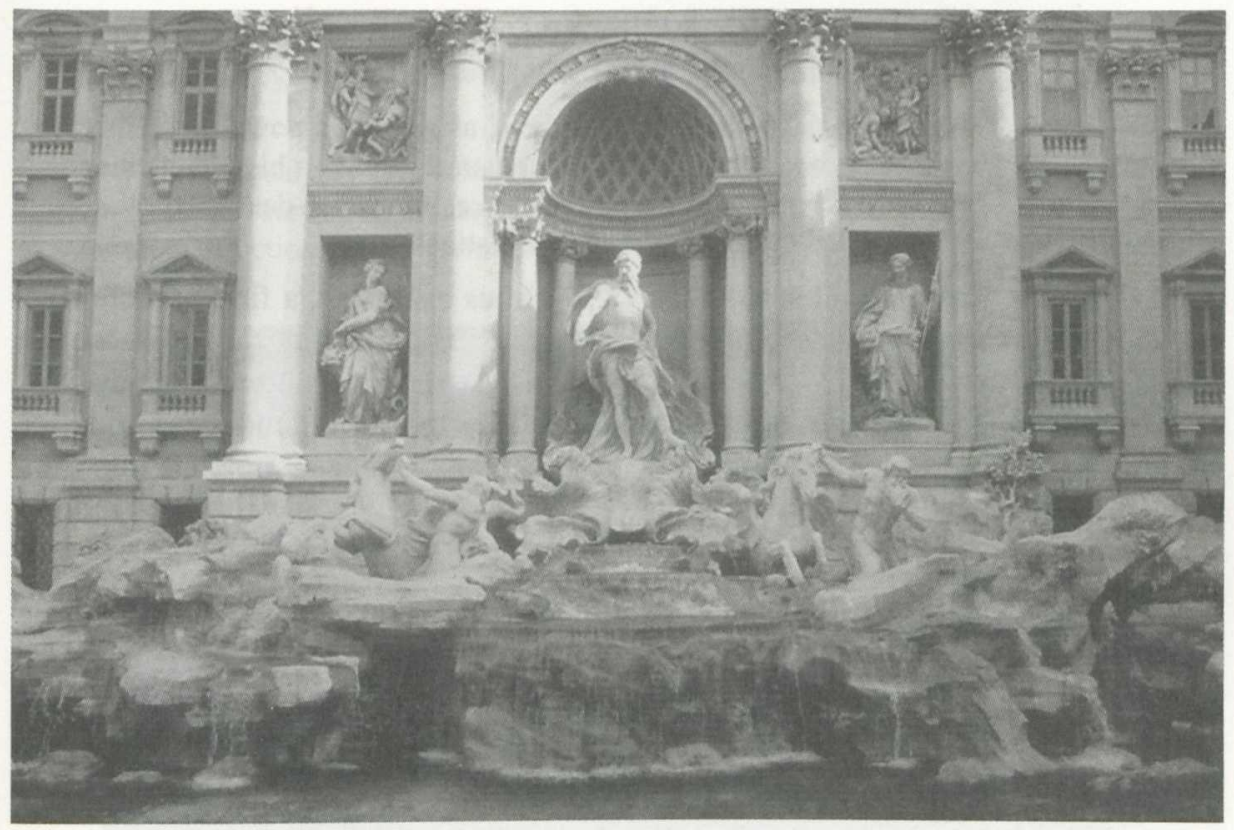

Fig. 11: Nicola Salvi (architecture), Giovanni Battista Maini et al. (sculpture), Fontana di Trevi, detail.

Today, Fontana di Trevi is dominated by a colossus who appears as a commander on top of the abundant cascades of Aqua Virgo and over two powerfully expansive couples of Tritons with hippocampi (fig. 11). ${ }^{23}$ Nicola Salvi, the author of the fountain, dedicated detailed >Philosophical Arguments« (Ragioni filosofiche) to these central figures, preserved in a manuscript of the Biblioteca Vaticana that collects materials for the defense of the controversial architect. ${ }^{24}$ Salvi's Ragioni make explicit that he intended to visualize a fundamental principle of natural philosophy. To be sure, the Roman architect was qualified to meet the requirements of this idea. Not only was he educated in lingua Latina, eloquenza, and storia, but also in philosophy, mathematics, mechanics, and medicine. ${ }^{25}$ This almost perfectly matches the ideal of the universal architect-erudite outlined by Vitruvius and Alberti. For the central figure of the fountain, Salvi chose Oceanus,

23 On the fountain, see the excellent monograph of Pinto (1986); furthermore Schiavo (1956), Cooke (1956). A new online database sLineamenta<, run by the Bibliotheca Hertziana, Rome, will provide all the relevant materials related to the history of the Fontana di Trevi; see a test version at http://lineamenta.biblhertz.it.

24 Bibliotheca Apostolica Vaticana Lat. 8235. - The text is transcribed in Pinto (1986), App. II, 2.

25 Bibliotheca Apostolica Vaticana Lat. 8235, 19. 
who is »hardly, or not at all obscured by invented stories«. ${ }^{26} \mathrm{He}$ represents the enlivening effects of his element -

$[\ldots]$ a power as much greater than all the others, as a cosmic power is greater than other secondary powers; because Oceanus demonstrates through his effects that he is indeed one of those most powerful primordial forces of matter described by ancient philosophers as source and principle of infinite creations. ${ }^{27}$

Salvi describes the material substratum of Oceanus as umido, a fine-particle fluid which conserves and nourishes all material bodies: "penetrating the entire matter, winding itself through the vessels and the smallest voids of matter; it is recognizable as an eternal source of the unlimited creations of nature, and as an indefatigable cause of their preservation ${ }^{28}{ }^{2}$ At the fountain, Oceanus, »potenza non limitata«, should be represented as if he had just (appena) ascended from his hidden, subterranean arteries, in order to appear (fattosi visibile) in front of the »Popolo sulla Fontana di Trevi« and to bestow a command to his subordinate spectators (imporre un comando a $i$ suoi sudditi spettatori). ${ }^{29}$

Oceanus, as a mythological male personification, is not characterized by alternative narrative contexts, but by the fact, as Salvi underlines, that there has never been any story about him, because his meaning cannot be represented by narratives. To put it somewhat pointedly, as the most powerful force of matter, holding things together and enlivening them, Oceanus is nothing else than the vital matrix of all cultural productions, and, therefore, of any kind of narrative.

With the dominion of a non-verbal numen, however, the Roman Aqua Virgo lost its connections to local mythology. The conduit and its waters were, instead, inserted into a very large cosmological framework. This becomes evident in Salvi's program, where the specific waters of the fountain only play a secondary role. Now, the conduit represents a general and abstract, but at the same time extremely concrete concept - the forming, conserving, and nutritive potentia of water. Before, Aqua Virgo was connected to the cultural and physical continuity of the urbs; now its fountain represents and presents a power which preserves the entire orbis - the fluid element.

Or, to put it more precisely - humidity. The non-verbal character of Oceanus is exactly mirrored in the impossibility of representing his material substratum. Regarding esthetic strategies, Salvi's argument is highly significant. As an omnipresent principium that dominates matter, Oceanus should be imagined on a co-

$26 »[\ldots]$ poco, o nulla adombrato da favolose invenzioni [...]. «; Ibid., 34.

27 »[...] una Potenza tanto maggiore dell'altre, quanto una causa universale può dirsi maggiore di altre particulari, ovvero de'suoi effetti medesimi, ci fà chiaramente conoscere rappresentar esso uno di quei Primi potentissimi Agenti sabiliti frà le materali cose dagli Antichi Filosofi, come fonti, e principj d'infinite produzioni, che da essi dipendono [...].«; Ibid.

28 Ibid.

29 Ibid. 
lossal scale, as big as the entire world. But at the same time he is also invisibly small, as humidity, a liminal substance penetrating every body of the world.

Oceanus is

[...] continuously effective in every, even the most minute, part of created matter, where he [Oceanus] distributes and enlivens the nutritive elements that are necessary for the production of new forms. ${ }^{30}$

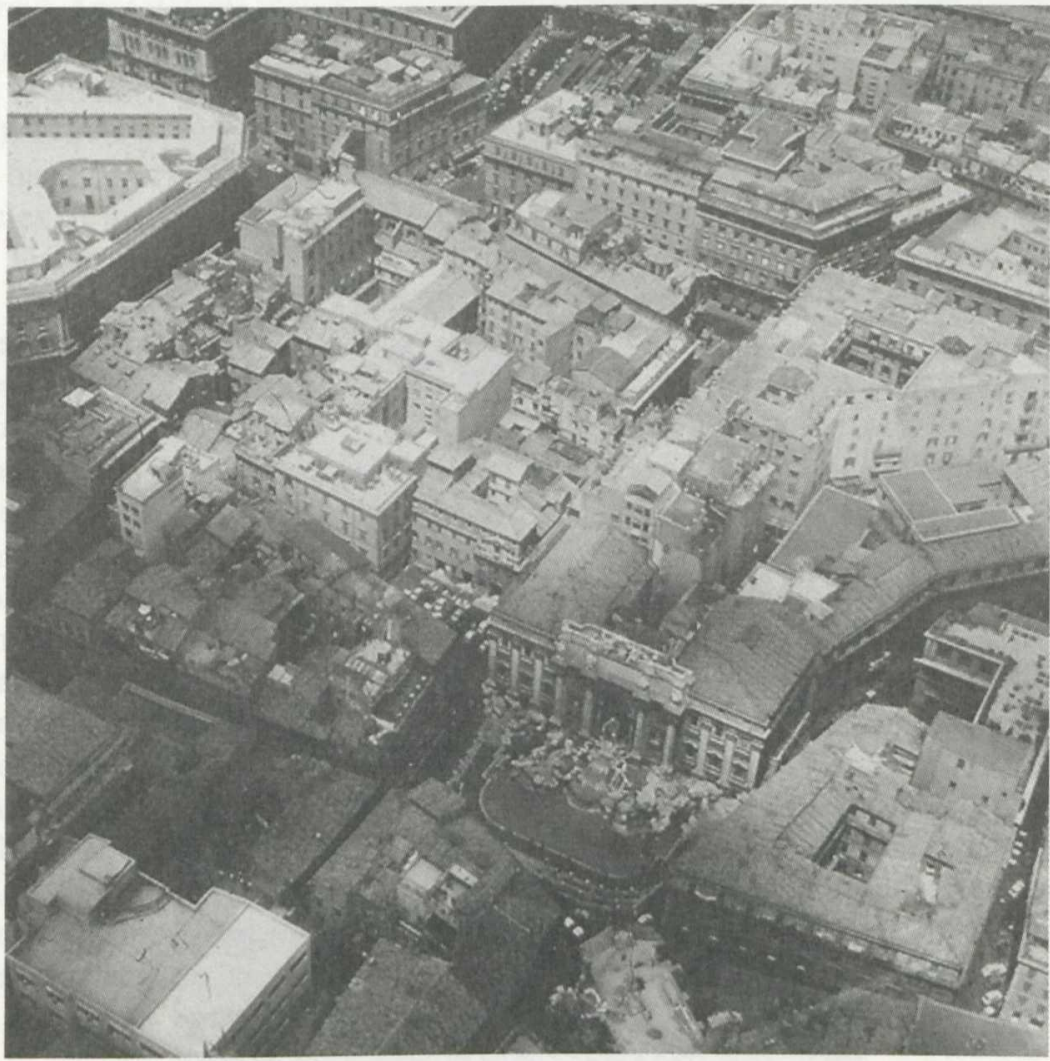

Fig. 12: Fontana di Trevi, aerial view.

there

Is there a way to represent the epiphany of this minimal-maximal entity? Yes $j /$ is, for instance, by overwhelming, expansive dimensions. Referring to the colossal size of Oceanus, an anonymous, contemporary defender of Salvi's fountain justified not only the enormous, much disputed size of the mostra, but also its impres-

30 n[...] e sempre operante in ciascheduna, benché minima, parte della materia creata, dove porta seco, distribuisce, e rende vivide le nutritive parti necessarie alla produzione delle nuove forme«; Ibid. 
sive, though again contested, expansion into the space of the piazza (fig. 12). ${ }^{31}$ In relation to the superlative of Oceanus, the consumption of space is well proportioned. The decorum of Oceanus has a name: excess.

Salvi's arguments follow a long and rich natural philosophical tradition, with particularly strong links to the widely diffused Mythologiae of Natalis Comes (1551, many editions). But within the context of contemporary science his ideas were also astonishingly modern.

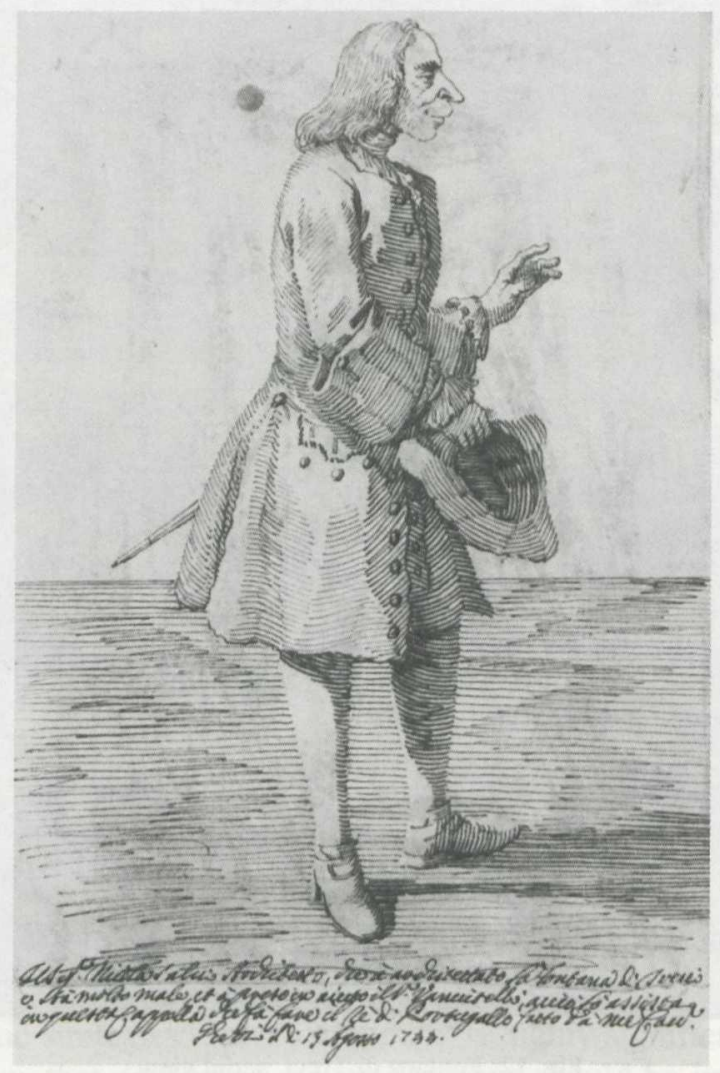

Fig. 13: Pier Leone Ghezzi, Nicola Salvi, 1744.

$31 》[\ldots]$ sporgono [the $s \operatorname{cog} l i]$ in fuori quanto può sufficientemente bastare ad una tazza proporzionata all'Oceano, ed al suo corteggio [...] il Salvi all'opposto merita di lode, per avere in un sito così ristretto, e senza Piazza conveniente, saputo inalzare un edificio così magnifico, così proporzionato, e cotanto decorosamente ornato, e secondo le leggi dell'arte, e corrispondente in tutto all'Allegoria intrapresa, siccome può riconoscersi in rileggendo la descrizione del medesimo Salvi« - Bibliotheca Apostolica Vaticana Lat. 8235, 133. 
Far from being belated hermetic philosophy, the discourse on the nature of the smallest particles of matter was central to Italian physics and natural philosophy in the $17^{\text {th }}$ and early $18^{\text {th }}$ century. These discourses went well beyond the circle of Jesuit scientists and the tantalizing problem of transsubstantiation. Recently (1998), William R. Shea, Renato Romano, and Manlio Iofrida demonstrated that the followers of Galilei were also involved into the debate. Members of the Accademia del Cimento and atomists like Sébastien Basson (Philosophia naturalis adversus Aristotelem, 1621) ${ }^{32}$, Etienne de Clave (Nouvelle lumière philosophique, 1641), Claudio Berigardo (Dubitationes in Dialogum Galilaei Galilaei, 1632) ${ }^{33}$, Niels Stensen (De solido naturaliter contento dissertationis prodromus, 1669 und 1763), Lorenzo Bellini (Discorsi di anatomia, 1741/1744) ${ }^{34}$ - all these authors were busily working to explain the forming and deforming forces of the smallest particles of matter, the causes for preservation and disintegration. Calor and fluidum feature prominently in these debates. The universalist and canonicus Giacinto Gimma, for instance, vehemently argued, like his teacher, Elia Astorini (Ars Magna), against the dominating Cartesian mechanics with reference to an wantichissima sapienza italica«, developed and refined until his own days - the atomism of Pythagoras and Lucretius (Idea della Storia dell'Italia letterata, 1723). Gimma objects to any kind of pan-vitalism; but he believes, nevertheless, in three shumors (sughi) which, through their virtu vitale and forza intrinseca, cause hardening and dissolving of matter in minerals. ${ }^{35}$

Against the background of history of science, the actuality of Salvi's Oceanus becomes evident - no deity contaminated by fables, but a non-verbal arché of natural philosophy. His enlivening powers - pieno di un vivido succo (Salvi) continued and transformed the >biological idea of a surviving urbs represented by the technological miracle of the Aqua Virgo.

As a tragic irony responding to this concept, Salvi, the architect-physician (fig. 13), was paralyzed by a stroke after he penetrated the subterranean vene of the Aqua Virgo in 1744. Entering the ancient body of his sonly daughter< (unicogenita), poisonous germs, not seeds of life, permeated his own arteries ( $\mathrm{se}$ gli intromisero nel sangue), as his anonymous biographer bitterly remarked (fig. 1). ${ }^{36}$

32 Cf. Iofrida (1998), 874.

33 Ibid. 890.

34 Cf. ibid. 905.

35 Ibid. 917. - On Gimma see also Vasoli (1970); Ferrone (1982), 469-478.

36 Bibliotheca Apostolica Vaticana Lat. 8235, 25. 


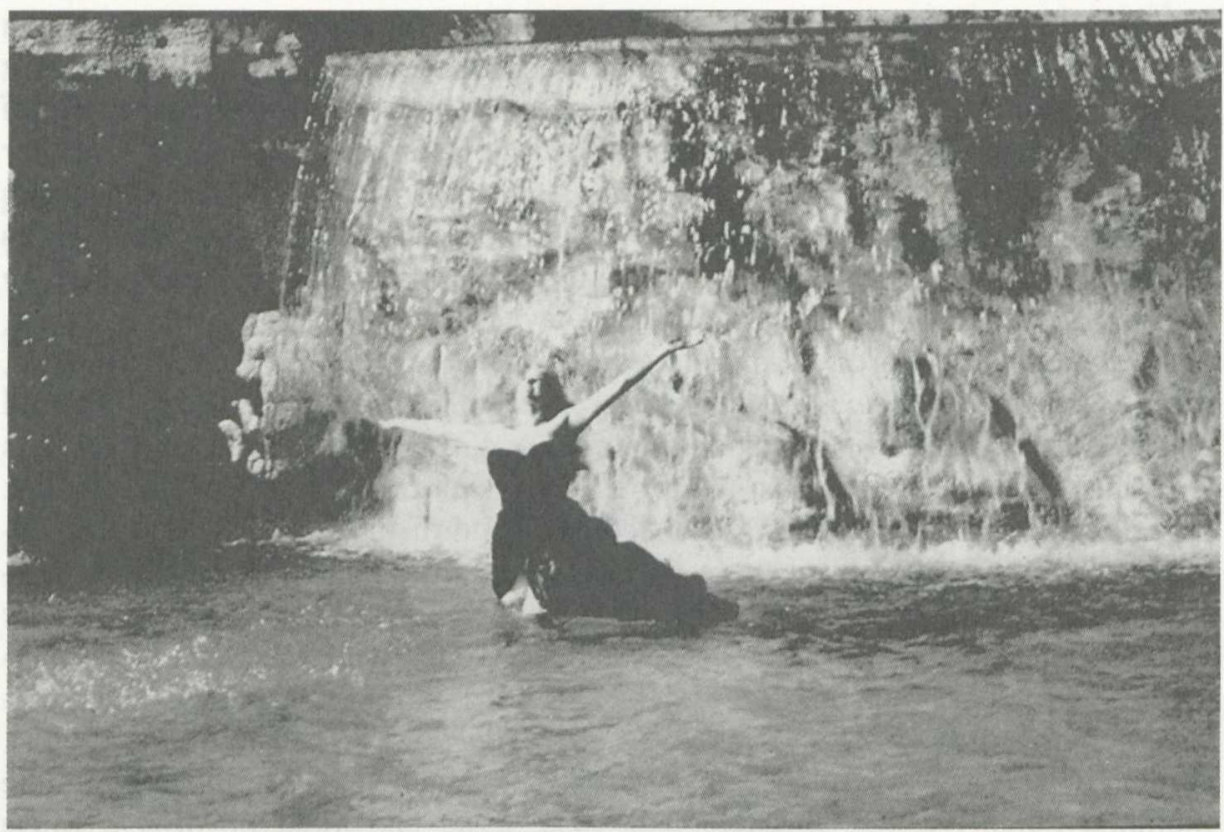

Fig. 14: Anita Ekberg in Federico Fellini's La dolce vita (1960).

His terrible and, in the end, deadly decease responds to Salvi's paradoxical effort to connect the most abstract to the most concrete, to stage a materialistic allegory in order to overwhelm the senses - a terrific non-verbal and non-local transformation of local history. It's another story that the nocturnal nymph of Aqua Virgo succeeded after 1960 in triumphantly returning to the collective imagination again as >Sylvia<, goddess of the woods (fig. 14).

\section{Bibliography}

Bredekamp, Horst, The Lure of Antiquity and the Cult of the Machine. The Kunstkammer and the Evolution of Nature, Art and Technology, Princeton 1995.

Bruun, Christer/Saastamoinen, Ari (ed.), Technology, ideology, water. From Frontinus to the Renaissance and beyond, Rome 2003.

Cecchelli, Carlo, S. Maria in Via, Rome (n. d.) (= Le chiese di Roma illustrate, 14).

Ceen, Allan, The Quartiere de'Banchi. Urban Planning in Rome in the First Half of the Cinquecento, New York/London 1986.

Chiflet, Jean, Aqua virgo, fons Romae celeberrimus, et prisca religione sacer. Opus aedilitatis M. Agrippae in vetere annulari gemma, n. p. 1662. 
Coates-Stephens, Robert, »The water-supply of early medieval Rome«, in: Technology, ideology, water. From Frontinus to the Renaissance and beyond, ed. Christer Bruun/ Ari Saastamoinen, Rome 2003, 81-113.

Cooke, Hereward Lester, »The documents relating to the Fountain of Trevi«, in: The Art Bulletin 38 (1956), 149-173.

Davis, Charles, »Villa Giulia e la `Fontana della Vergine««, in: Psicon 3 (1976/1977), 133-141.

D’Onofrio, Cesare, Le fontane di Roma, 3. ed. Rome 1986.

Ferrone, Vincenzo, Scienza, natura, religione. Mondo newtoniano e cultura italiana nel primo Settecento, Naples 1982.

Franzini, Giovanni Domenico, Descrittione di Roma antica e moderna, Rome 1643.

Graevius, Johannes Georgius, Thesaurus Antiquitatum Romanarum [...], Bd. 4, Venice 1732 .

Gregorovius, Ferdinand, Geschichte der Stadt Rom im Mittelalter, 4. Aufl. Stuttgart 1892.

Iofrida, Manlio, »Atomisten, Naturphilosophen, Mediziner, Enzyklopädisten«, in: Die Philosophie des 17. Jahrhunderts (Grundriß der Geschichte der Philosophie, begr. v. Friedrich Ueberweg), hg. v. Jean-Pierre Schobinger, Bd. 2, Basel 1998, 870-920.

Kraus, Theodor, Hekate, Heidelberg 1960.

Krautheimer, Richard, Roma. Profilo di una città, 312-1308, Rome 1981.

Landels, John G., Die Technik in der antiken Welt, München 1979.

Lombardi, Leonardo, „L'ingegneria idraulica romana rivisitata in epoca rinascimentale e barocca«, in: Technology, ideology, water. From Frontinus to the Renaissance and beyond, ed. Christer Bruun/Ari Saastamoinen, Rome 2003, 259-276.

MacDougall, Elisabeth Blair, »The sleeping nymph. Origins of a humanist fountain type«, in: The Art Bulletin 57 (1975), 357-365.

MacDougall, Elisabeth Blair, „L'Ingegnoso Artifizio. Sixteenth Century Garden Fountains in Rome«, in: Fons Sapientiae. Renaissance Garden Fountains (5th Dumbarton Oaks Colloquium on the History of Landscape Architecture 1977), ed. Elisabeth Blair MacDougall, Washington D. C. 1978, 87-113.

Pace, Pietrantonio, Gli acquedotti di Roma e il De Aquaeductu di Frontino, Rome 1986.

Panofsky, Erwin, A mythological painting by Poussin, Stockholm 1960.

Pinto, John, The Trevi Fountain, New Haven 1986.

Romano, Renato, »Die Accademia del Cimento«, in: Die Philosophie des 17. Jahrhunderts (Grundriß der Geschichte der Philosophie, begr. v. Friedrich Ueberweg), hg. v. Jean-Pierre Schobinger, Bd. 2, Basel 1998, 842-869.

Schiavo, Armando, La Fontana di Trevi e le altre opere di Nicola Salvi, Rome 1956.

Shea, William R., »Die Schule Galileis«, in: Die Philosophie des 17. Jahrhunderts (Grundriß der Geschichte der Philosophie, begr. v. Friedrich Ueberweg), hg. v. JeanPierre Schobinger, Bd. 2, Basel 1998, 823-841.

Simon, Erika, Die Götter der Römer, Darmstadt 1990.

Taylor, Rabun M., Public Needs and Private Pleasures: Water Distribution, the Tiber River, and the Urban Development of Ancient Rome, Rome 2000.

Valesio, Francesco, Diario di Roma, hg. v. Gaetana Scano/Giuseppe Graglia, 6 Bde., Milan 1977-1979.

Vasoli, Cesare, »L'abbate Gimma e la `Nova Encyclopedia‘ (Cabbalismo, lullismo, magia e snuova scienza in un testo della fine del Seicento)«, in: Studi in onore di Antonio Corsano, Manduria 1979, 787-846. 


\section{Abbildungsverzeichnis}

Fig. 1, 2, 5, 6, 12, 13: Pinto (1986).

Fig. 3, 4, 10, 11:

Author.

Fig. 7:

Aikema, Bernard/Brown, B. L. (ed.), Renaissance Venice and the North: Crosscurrents in the time of Bellini, Dürer, and Titian (exhibition catalogue), New York 1999.

Fig. 8: Simon (1990).

Fig. 9: Art Resource.

Fig. 14:

Kezich, Tullio, Su La Dolce Vita (...), Venice 1996. 